\title{
PENGARUH PROMOSI TERHADAP LOYALITAS KONSUMEN PADA PT. ALAM TERANG MANDIRI CABANG PEMATANGSIANTAR
}

\author{
Oleh: \\ Desi Ratnasari Silalahi \\ S1 Manajemen \\ Darwin Lie, Marisi Butarbutar, Efendi
}

\begin{abstract}
Abstraksi
Rumusan masalah dalam penelitian adalah bagaimana pengaruh promosi terhadap loyalitas konsumen pada PT. Alam Terang Mandiri cabang Pematangsiantar. Adapun metode penelitiaan yang digunakan adalah metode eksplanatori. Sampel yang digunakan dalam penelitian ini adalah 107 responden. Jenis data yang digunakan dalam penelitian ini adalah data kualitatif dan kuantitatif. Sumber data yang digunakan dalam penelitian ini adalah data primer dan data sekunder. Untuk mengukur loyalitas konsumen (Y) dan promosi (X) penulis menyebarkan kuesioner kepada para konsumen dan dianalisis dengan analisa deskriptif kualitatif dan deskriptif kuantitatif dengan regresi, korelasi, koefisien determinasi, dan uji t.

Hasil analisis menunjukkan pengaruh positif variabel $\mathrm{X}$ terhadap variabel $\mathrm{Y}$ dengan persamaan regresi $\hat{Y}=$ $0,15+1,00 X$. Kekuatan hubungan kedua variabel adalah kuat, ditunjukkan nilai $r$ sebesar 0,62. Dari perhitungan koefisien determinasi di atas ditunjukkan bahwa tinggi rendahnya loyalitas konsumen dapat dijelaskan oleh kegiatan promosi sebesar $38,30 \%$, sedangkan sisanya $61,70 \%$ dijelaskan oleh faktor lain yang tidak dibahas dalam penelitan seperti kualitas produk, pelayanan jasa dan kepuasan konsumen. Dari hasil pengolahan data kuesioner serta perhitungan data kuesioner, penulis mendapatkan kesimpulan bahwa promosi berpengaruh positif terhadap loyalitas konsumen pada PT. Alam Terang Mandiri cabang Pematangsiantar. Hal ini dibuktikan secara matematis melalui uji hipotesis, dimana hasil uji $\mathrm{t}_{(\text {hit }}=8,07>\mathrm{t}_{(\mathrm{tab})}=1,98$. Dalam kegiatan promosi diharapkan perusahaan harus lebih meningkatkan program promosi penjualan guna mendorong pembelian produk sehingga menciptakan loyalitas konsumen.
\end{abstract}

Kata Kunci: Promosi dan Loyalitas Konsumen.

\section{Abstraction}

Formula of internal issue of research is how promotion influenced to loyalitas consumer at PT. Alam Terang Mandiri branch the Pematangsiantar. Sampel used in this research is 107 responden. Data type used in this research [is] data qualitative and quantitative. Data source used in this research [is] data of primary and data secunder. To measured loyality consumers $(\mathrm{X})$ and promotions $(\mathrm{Y})$. Analysed with the descriptive analysis qualitative and quantitative descriptive by regresi, correlation, coefficient determinasi, and test

Result of analysis show the positive influence of variable $\mathrm{X}$ to variable $\mathrm{Y}$ with the equation regresi $\mathrm{Y}=$ $0.15+1,00 \mathrm{X}$. The corelation strength of variable is strength, shown by value $\mathrm{r}=0.62$. From calculation of coefficient determinasi above indicated that high lower the explainable nya loyalitas consumer by promotion activity of equal to $38,30 \%$, while the rest $61,70 \%$ explained by other, dissimilar factor which is not discussed in elite of like product quality, service activities and consumer satisfaction. Conclusions that promotions have an effect on positive to loyalitas consumer at PT. Alam Terang Mandiri branch the Pematangsiantar. This Matter is proved mathematically through hypothesis test, where result test the $t(h i t)=8.07>t(t a b)=1.98$. In promotion activity expected [by] a company have to be more improve the program [of] sales promotion utilize to push the product purchasing so that create the loyalitas consumer

Keywords: Promotion and Loyality Consumers.

\section{A. PEndahuluan}

\section{Latar Belakang Masalah}

Aktifitas promosi merupakan perwujudan dari fungsi informatif sehingga dengan adanya promosi diharapkan ada reaksi dari pemakai, baik aktual maupun potensial, yang muncul dalam berbagai bentuk mulai dari timbulnya kesadaran atau tahu akan keberadaan suatu produk, sampai kepada tindakan untuk memanfaatkannya. Promosi merupakan pemasaran yang dirancang untuk jangka panjang dan pendek yang harus dilaksanakan oleh semua bagian pemasaran perusahaan. Adapun cara yang ditempuh masing-masing perusahaan dalam memasarkan produknya berbeda satu dengan yang lainnya termasuk dalam upaya mempromosikan produknya agar konsumen tertarik.

Loyalitas konsumen merupakan kunci keberhasilan pemasaran jangka panjang. Untuk mendapatkan loyalitas pelanggan, institusi atau perusahaan perlu melakukan strategi pemasaran 
yang tepat agar dapat mempengaruhi loyalitas pelanggannya. Menciptakan hubungan yang kuat dan erat dengan pelanggan adalah mimpi semua pemasar.

PT. Alam Terang Mandiri adalah perusahaan yang memproduksi bibit anak ayam boiler beserta pakan dan obat-obatan untuk ternak ayam tersebut. Perusahaan ni telah dikenal baik dalam kalangan masyarakat. Banyak hal yang dapat mempengaruhi pelanggan, salah satunya adalah upaya promosi. Berdasarkan data sebanyak 200 konsumen yang diperoleh dari PT. Alam Terang Mandiri cabang Pematangsiantar, diketahui bahwa konsumen yang datang secara berulang-ulang sebanyak 145 konsumen $(72,5 \%)$ dan konsumen yang datang hanya sekali sebanyak 55 konsumen $(27,5 \%)$.

Dalam upaya meningkatkan loyalitas konsumen, PT. Alam Terang Mandiri melakukan promosi dengan cara: penjualan perseorangan, dimana perusahaan memberikan informasi harga kepada konsumen, memberikan potongan harga kepada pelanggan setia, serta memberikan pelayanan yang memuaskan kepada setiap konsumen. Cara lainnya adalah promosi penjualan, dimana perusahaan melakukan pembagian sampel setiap produk baru berupa pakan dan obat-obatan dan memberikan paket bonus berupa parsel kepada konsumen dihari-hari besar keagamaan. Melalui hal tersebut diharapkan mampu meningkatkan loyalitas konsumen terhadap perusahaan.

\section{Rumusan Masalah}

Berdasarkan uraian dari latar belakang di atas, maka rumusan masalah penelitian ini adalah:

a. Bagaimana kegiatan Promosi yang dilakukan dan gambaran loyalitas konsumen pada PT. Alam Terang Mandiri cabang pematangsiantar.

b. Seberapa besar pengaruh promosi terhadap loyalitas konsumen pada PT.Alam Terang Mandiri cabang Pematangsiantar.

\section{Tujuan Penelitian}

Adapun tujuan penelitian yang dilakukan adalah sebagai berikut:

a. Untuk mengetahui kegiatan promosi yang dilakukan dan gambaran loyalitas konsumen pada PT. Alam Terang Mandiri cabang pematangsiantar.

b. Untuk mengetahui besarnya pengaruh promosi terhadap Loyalitas Konsumen pada PT. Alam Terang Mandiri cabang pematangsiantar.

\section{METODE PENELITIAN}

Desain penelitian merupakan suatu cara yang sistematis dan objektif dengan maksud untuk memperoleh data atau mengumpulkan keterangan untuk diteliti. Adapun Desain penelitian yang digunakan dalam penulisan skripsi ini adalah Penelitian Kepustakaan (Library Research) dan Penelitian Lapangan (Field Research).

Teknik pengumpulan data yang dilakukan penulis dalam penelitian ini adalah berupa Kuesioner, Wawancara dan Dokumentasi. Tehnik analisa data yang digunakan dalam penelitian ini antara lain Tehnik Analisa Deskriptif Kualitatif dan Tehnik Analisa Deskriptif Kuantitatif.

\section{B. LANDASAN TEORI}

Menurut Kotler dan Amstrong (2008:5), "pemasaran adalah sebuah proses perusahaan menciptakan nilai untuk konsumennya dan membangun hubungan kuat dengan konsumen dengan tujuan untuk menciptakan nilai keuntungan dari konsumen". Sedangkan menurut Kurtz (2008:7) "pemasaran adalah fungsi organisasi dan sebuah proses, untuk mengkomunikasikan, menciptakan dan mengirimkan nilai untuk konsumen dan mengatur hubungan dengan konsumen sebagai cara menguntungkan perusahaan dan juga pihak berkepentingan". Dari beberapa defenisi diatas,dapat disimpulkan bahwa pemasaran merupakan upaya untuk mendapatkan kepuasan pelanggan di tengah persaingan, perusahaan harus mengerti dahulu apa kebutuhan dan keinginan konsumennya.

Pemasaran dapat dilakukan oleh perusahaan dengan menggunakan kemampuan dan keterampilan yang dimiliki oleh para pimpinan perusahaan maupun manajer perusahaan. Kemampuan dan keterampilan tersebut dapat dilakukan dengan merencanakan dan mengelola hubungan dagang dengan perusahaan lain yang biasanya dikenal dengan manajemen pemasaran.

Kotler dan Amstrong (2004:16) mengatakan "Manajemen Pemasaran adalah analisis, perencanaan, implementasi, dan pengendalian terhadap program yang dirancang untuk menciptakan, membangun, dan mempertahankan pertukaran dan hubungan yang menguntungkan dengan pasar sasaran dengan maksud untuk mencapai tujuan-tujuan organisasi". Dari defenisi diatas dapat disimpulkan bahwa manajemen pemasaran meliputi semua keputusan yang dibuat dalam merancang dan melaksanakan rencana pemasaran dalam rangka menerapkan strategi pemasaran. Analisa peluang pasar merupakan faktor penting dalam keberhasilan maupun kegagalan strategi pemasaran.

Boyd (2000:21) menjelaskan bahwa bauran pemasaran adalah kombinasi dari variabel-variabel pemasaran yang dapat dikendalikan oleh manajer untuk menjalankan strategi pemasaran dalam upaya mencapai tujuan perusahaan didalam pasar sasaran tertentu. Marketing Mix adalah istilah yang digunakan untuk menerangkan kombinasi dari empat elemen yang membentuk inti dari program pemasaran suatu pemasaran. Elemen-elemen itu adalah produk (product), harga (price), saluran distribusi (place) dan kegiatan promosi (promotion).

Menurut Sukotjo (2001:41), "promosi adalah upaya memberitahu dan mengingatkan konsumen akan keberadaan barang atau jasa tersebut dipasar dan manfaatnya". Kotler (2002:145) mendefinisikan promosi sebagai: "komunikasi dari para pemasar yang menginformasikan, membujuk, dan mengingatkan calon pembeli suatu produk dalam rangka mempengaruhi pendapat mereka atau 
memperoleh suatu respons". Dan menurut Tjiptono (2005:35) pada hakekatnya, "promosi adalah salah satu bentuk komunikasi pemasaran, yakni aktivitas pemasaran yang berusaha menyebarkan informasi, mempengaruhi, atau membujuk, dan mengingatkan pasar sasaran atas perusahaan dan produknya yang ditawarkan perusahaan yang bersangkutan". Jadi, dapat disimpulkan bahwa promosi adalah suatu kegiatan perusahaan untuk menginformasikan, memperkenalkan, membujuk dan mengingatkan suatu produk atau jasa pada konsumen.

Menurut Kotler dan Amstrong (2004:622), "Bauran Promosi adalah kombinasi dari alat promosi termasuk periklanan, penjualan perseorangan, promosi penjualan, hubungan masyarakat, dan pemasaran langsung digunakan untuk mencapai pasar sasaran dan memenuhi tujuan organisasi secara keseluruhan". Ada beberapa tugas khusus bauran promosi, yaitu Advertising, Personal Selling, Sales Promotion dan Publicity.

Griffin (2003:31) mendefinisikan loyalitas berdasarkan perilaku membeli. Pelanggan yang loyal adalah melakukan pembelian berulang secara teratur, membeli antar lini produk dan jasa, mereferensikan kepada orang lain, menunjukkan kekebalan terhadap tarikan dari pesaing. Sedangkan Lupioyandi dan Hamdani (2006:193) mendefenisikan loyalitas sebagai komitmen yang dipegang kuat untuk membeli ulang atau berlangganan lagi produk atau jasa tertentu di masa depan meskipun ada pengaruh situasi dan usaha pemasaran yang menyebabkan peralihan perilaku.. Dari defenisi di atas dapat disimpulkan bahwa loyalitas konsumen merupakan suatu keinginan yang kuat yang ditunjukkan oleh para konsumen untuk membeli secara berulang-ulang kembali suatu produk atau jasa di masa depan bahkan dengan sukarela merekomendasikanya pada pihak lain.

Loyalitas pelanggan dapat diandalkan untuk memprediksi pertumbuhan penjualan dan keuangan serta kelangsungan perusahaan. Menurut Griffin (2003:31) berikut ada beberapa indikator loyalitas berdasarkan perilaku pelanggan, yakni:

1) Melakukan pembelian ulang secara teratur

2) Membeli antar lini produk dan jasa

3) Mereferensikan kepada orang lain

4) Menunjukkan kekebalan terhadap pesaing

Menurut Mardalis (2005:3), secara umum loyalitas dapat diukur dengan cara sebagai berikut:

1. Urutan pilihan (choice sequence)

2. Proporsi pembelian (proportion of purchase)

3. Preferensi (preference)

4. Komitmen (commitment)

Kotler dan Keller (2009:153) mengemukakan bahwa menciptakan hubungan yang kuat dan erat dengan pelanggan adalah mimpi semua pemasar dan hal ini sering menjadi kunci keberhasilan pemasaran jangka panjang. Sedangkan, menurut Peter dan Olson (2002:203) "Promosi terhadap konsumen dapat menjadi usaha bagi perusahaan untuk menjaga hubungan kepada konsumen tetap loyal."
Tjiptono (2011:34) mengungkapkan bahwa promosi dapat meningkatkan kesadaran akan merek, mendorong pencobaan terhadap merek tersebut dan menekankan pembelian yang berulang. Pengiklanan berinteraksi dengan pengalaman masa lalu dalam menggunakan suatu merek untuk mendorong kecenderungan melakukan pembelian berulang. PT. Alam Terang Mandiri cabang Pematangsiantar melakukan kegiatan promosi melalui penjualan perseorangan, dimana perusahaan berupaya semaksimal mungkin memberikan informasi harga kepada konsumen, memberikan potongan harga kepada pelanggan setia, serta memberikan pelayanan yang memuaskan kepada setiap konsumen.

Selanjutnya promosi penjualan, dimana perusahaan melakukan pembagian sampel setiap produk baru berupa pakan dan obat-obatan ternak kepada konsumen dan memberikan paket bonus berupa parsel kepada konsumen dihari-hari besar keagamaan. Melalui hal tersebut diharapkan mampu meningkatkan loyalitas konsumen terhadap perusahaan.

\section{PEMBAHASAN}

\section{Analisa}

\section{a. Deskripsi Responden}

Berikut adalah tabel-tabel yang dibutuhkan untuk mengetahui berbagai kriteria keadaan umum para pelanggan yang akan dijadikan sebagai responden.

Tabel 1

Komposisi responden berdasarkan jenis kelamin.

\begin{tabular}{|c|c|c|c|}
\hline No. & $\begin{array}{c}\text { Jenis } \\
\text { Kelamin }\end{array}$ & $\begin{array}{c}\text { Frekuensi } \\
(\mathbf{f})\end{array}$ & $\begin{array}{c}\text { Persentase } \\
(\mathbf{\%})\end{array}$ \\
\hline 1 & Laki-laki & 82 & $76,4 \%$ \\
\hline 2 & Perempuan & 25 & $23,6 \%$ \\
\hline \multicolumn{2}{|c|}{ Jumlah } & 107 & $100 \%$ \\
\hline
\end{tabular}

Sumber: Data primer diolah.

Tabel 1 menunjukkan bahwa jumlah pelanggan yang datang berulang pada PT. Alam Terang Mandiri Cabang Pematangsiantar ada sebanyak 107 orang yang terdiri dari 82 orang $(76,4 \%)$ pelanggan berjenis kelamin laki-laki, sedangkan 25 orang $(23,6 \%)$ pelanggan berjenis kelamin perempuan. Sebagian besar pelanggan yang datang berulang di PT. Alam Terang MAndiri Cabang Pematangsiantar berjenis kelamin laki-laki. dikarenakan pekerjaan tersebut beresiko tinggi,. dimana para pelanggan harus terjun langsung ke lapangan untuk melihat keadaan produk (ayam boiler) di kandang yang dilakukan pada malam hari .

Tabel 2

Komposisi responden berdasarkan usia

\begin{tabular}{|c|c|c|c|}
\hline No. & Usia & $\begin{array}{c}\text { Frekuensi } \\
\text { (f) }\end{array}$ & $\begin{array}{c}\text { Persentase } \\
(\boldsymbol{\%})\end{array}$ \\
\hline 1 & $\leq 30$ tahun & 5 & $4,67 \%$ \\
\hline 2 & $31-40$ tahun & 74 & $69,16 \%$ \\
\hline 3 & $41-50$ tahun & 28 & $26,17 \%$ \\
\hline & Jumlah & 107 & $100 \%$ \\
\hline
\end{tabular}


Sumber: Data primer diolah.

Tabel di atas menunjukkan bahwa sebagian besar usia responden adalah kelompok usia 31-40 tahun sebanyak 74 orang $(69,16 \%)$. Setelah itu, kelompok usia 41-50 tahun ada sebanyak 28 orang $(26,17 \%)$, dan 5 orang $(4,67 \%)$ adalah kelompok usia $\leq 30$ tahun. Tabel di atas memberikan gambaran bahwa mayoritas pelanggan yang datang adalah pelanggan yang berusia antara 31-40 tahun, hal ini dikarenakan usia tersebut merupakan usia produktif.

Tabel 3

Komposisi responden berdasarkan pendidikan terakhir.

\begin{tabular}{|c|l|c|c|}
\hline No. & $\begin{array}{c}\text { Pendidikan } \\
\text { Terakhir }\end{array}$ & $\begin{array}{c}\text { Frekuensi } \\
\text { (f) }\end{array}$ & $\begin{array}{c}\text { Persentase } \\
(\boldsymbol{\%})\end{array}$ \\
\hline 1 & SMA & 82 & $76.63 \%$ \\
\hline 2 & Diploma & 15 & $14.02 \%$ \\
\hline 3 & Sarjana & 10 & $9.35 \%$ \\
\hline \multicolumn{2}{|c|}{ Jumlah } & 107 & $100 \%$ \\
\hline
\end{tabular}

Sumber: Data primer diolah.

Tabel di atas menunjukkan bahwa ada sebanyak 82 responden (76.63\%) dengan pendidikan terakhir SMA sederajat, 15 responden (14.02\%) dengan pendidikan terakhir diploma dan 10 responden $(9.35 \%)$ dengan pendidikan sarjana. Mayoritas responden berpendidikan terakhir SMA. Hal ini dikarenakan perusahaan tidak mematokkan pelanggan dari tingkat pendidikannya.

\section{b. Analisa Deskriptif Kualitatif}

Berdasarkan masalah diatas, maka penulis menganalisa dan mengevaluasi berdasarkan teoriteori, catatan, dan keadaan di PT. Alam Terang Mandiri cabang Pematangsiantar. Selain itu, penulis juga menyebarkan kuesioner kepada para pelanggan yang berisi pertanyaan tentang dimensi kegiatan promosi dan tanggapan pelanggan dalam wujud tingkat loyalitas pelanggan.

Analisa deskriptif dimaksudkan untuk mendapatkan gambaran atau deskripsi mengenai tanggapan dari pegawai mengenai pengaruh PT. Alam Terang Mandiri cabang Pematangsiantar. Sesudah pengujian data, maka langkah selanjutnya peneliti melakukan pengkajian analisis kualitatif sebagai gambaran fenomenal dari variabel penelitian pada saat sekarang ini. Adapun penetapan kriteria nilai rata-rata jawaban dari responden tersebut dimasukkan ke dalam kelas-kelas interval dimana penentuan intervalnya memakai rumus sebagai berikut:

Panjans kelas $=\frac{\text { Data terbesas }- \text { Data terkecil }}{\text { G (jumlah kelas interva!) }}$

Sumber: Sugiyono (2010:80)

Kriteria:

Nilai tertinggi $=5$

Nilai terendah $=1$

Jumlah kelas $=5$

Dari rumus di atas diperoleh interval kelas = 0,8, sehingga berlaku ketentuan kategori dengan hasil sebagai berikut:

Tabel 4

Nilai Interval dan Kategori Jawaban Responden.

\begin{tabular}{|c|c|}
\hline $\begin{array}{c}\text { Nilai } \\
\text { Interval }\end{array}$ & Kategori \\
\hline $1,00-1,80$ & $\begin{array}{c}\text { Sangat Tidak Baik/Sangat } \\
\text { Rendah }\end{array}$ \\
\hline $1,81-2,60$ & Tidak Baik/Rendah \\
\hline $2,61-3,40$ & Kurang Baik/Cukup Tinggi \\
\hline $3,41-4,20$ & Baik/Tinggi \\
\hline $4,21-5,00$ & Sangat Baik/sangat Tinggi \\
\hline
\end{tabular}

Sumber: Hasil Pengolahan Data.

\section{Promosi pada PT. Alam Terang Mandiri cabang Pematangsiantar}

PT. Alam Terang Mandiri merupakan suatu perusahaan yang bergerak dalam bidang distributor unggas (Ayam boiler). Jenis promosi yang diterapkan PT. Alam Terang Mandiri cabang Pematangsiantar adalah penjualan perseorangan (Personal Selling) dan promosi penjualan (Sales Promotion). Dalam kegiatan promosi tersebut terdapat kendala tidak selalu berjalan lancar salah satunya dikarenakan sales promotor kurang menguasai produk yang telah disediakan perusahaan.

Dengan mempromosikan produk kepada pelanggan, PT. Alam Terang Mandiri selalu mengutamakan kepuasan pelanggan dengan memberikan pelayanan yang ramah, cepat dan tepat. Akan tetapi, masih terdapat pelanggan yang mengeluhkan lokasi yang tidak berada dipusat kota.

PT. Alam Terang Mandiri selalu berusaha konsisten dalam melaksanakan kegiatan promosi yang efektif berdasarkan indikator yang digunakan untuk mewujudkan loyalitas konsumen pada PT. Alam Terang Mandiri Cabang Pematangsiantar, maka hasil penelitian menunjukkan nilai rata-rata dari keseluruhan jawaban responden dengan kriteria baik. Hal tersebut dapat dilihat dari mayoritas responden yang memberikan jawaban dengan kriteria yang baik pada setiap indikator, dengan penjabaran berikut.

Sebanyak 64 responden $(59,82 \%)$ memberi tanggapan positif dengan kriteria baik pada penyampaian informasi harga oleh tenaga penjual kepada konsumen dan pernyataan sangat baik dipilih oleh sebanyak 43 responden $(40,18 \%)$. Hal ini dikarenakan responden merasa bahwa informasi harga jelas sehingga konsumen mengetahui ketika adanya perubahan harga. Dengan demikian nilai rata-rata responden adalah 4,40 dengan kriteria sangat baik.

Untuk pertanyaan potongan harga yang diberikan tenaga penjual kepada konsumen, mayoritas responden menjawab cukup baik 38 responden $(35,51 \%)$, sebanyak 51 responden $(47,66 \%)$ menjawab baik, dan sebayak 18 responden $(16,83 \%)$ menjawab sangat baik. Perusahaan melakukan kebijakan dalam memberikan potongan harga bila konsumen melakukan pembelian dalam jumlah besar sesuai dengan ketentuan yang 
diberikan perusahaan. Dengan demikian nilai ratarata responden adalah 3,81 dengan kriteria baik.

Untuk indikator ketepatan waktu pemenuhan permintaan konsumen, khususnya dalam menyediakan produk, sebagian responden menjawab cukup baik, yaitu sebanyak 14 responden $(13,09 \%)$, 16 responden $(14,95 \%)$ menjawab sangat baik, selanjutnya 77 responden $(71,96 \%)$ memberikan jawaban baik. Konsumen selalu dipermudah dalam melakukan pemesanan barang tanpa harus menunggu lama. Dengan demikian nilai rata-rata responden adalah 4,01 dengan kriteria yang baik.

Tenaga penjual diharuskan mampu melayani dalam memenuhi permintaan konsumen untuk mengantarkan produk yang telah dipesan. Jawaban responden yang memberikan respon positif dengan kriteria baik sebanyak 32 responden $(29,90 \%), 34$ responden $(31,78 \%)$ menjawab dengan kriteria sangat baik, dan sebanyak 41 responden $(38,32 \%)$ memberikan jawaban cukup baik. Dengan demikian nilai rata-rata responden adalah 3.93 dengan kriteria baik.

Dari indikator promosi mengenai pembagian sampel baru pakan dan obat-obatan, mayoritas responden, yaitu sebanyak 58 responden $(54,20 \%)$ memberikan jawaban dengan kriteria baik, 49 responden $(45,80 \%)$ menjawab sangat baik. Perusahaan melakukan pembagian sampel baru tersebut guna merangsang konsumen dalam melakukan pemakaian akan produk baru tersebut. Dengan demikian nilai rata-rata responden adalah 4,54 dengan kriteria sangat baik.

Perusahaan ingin menunjukkan bentuk apresiasinya terhadap konsumen dengan memberikan paket bonus berupa parsel dihari-hari besar keagamaan mereka. Dari indikator kegiatan promosi terhadap loyalitas tersebut, sebanyak 14 responden $(13,09 \%)$ menjawab sangat baik, 77 responden $(71,98 \%)$ untuk kriteria baik dan 16 responden (14,95\%) menjawab cukup baik. Berdasarkan data tersebut, rata-rata nilai responden adalah 3,98 dengan kriteria baik.

Berdasarkan pertanyaan mengenai program yang dilakukan perusahaan dalam mendorong konsumen melakukan pembelian produk, sebagian responden menjawab dengan kriteria baik 61 responden $(57,00 \%)$ dan responden yang memberikan jawaban cukup baik sebanyak 46 responden $(43,00 \%)$. Perusahaan sudah menerapkan program yang matang untuk mendorong konsumen dalam melakukan pembelian produk yang telah disediakan. Dengan demikian nilai rata-rata responden adalah 3,57 dengan kriteria baik.

Adanya upaya yang dilakukan perusahaan guna mengubah opini konsumen terhadap produk yang dimiliki perusahaan ditunjukkan oleh 34 responden $(31,78 \%)$ yang menjawab cukup baik, 54 responden $(50,47 \%)$ yang menjawab baik dan 19 responden $(17,75 \%)$ yang menjawab sangat baik. Dengan demikian nilai rata-rata responden adalah 3,85 dengan kriteria baik.

\section{Loyalitas Konsumen pada PT. Alam Terang Mandiri cabang Pematangsiantar}

Berdasarkan data tanggapan responden, dapat diketahui nilai rata-rata sebesar 4,05 dengan kriteria tinggi. Hal tersebut dapat dilihat dari mayoritas responden yang memberikan jawaban dengan kriteria tinggi pada setiap indikator. Berikut penjabaran dari kuesioner yang diberikan kepada konsumen.

Minat konsumen dalam pembelian yang berulang memberikan nilai rata-rata responden dengan kriteria tinggi yaitu sebesar 4,18. Mayoritas responden $(58,87 \%)$ sebanyak 87 responden menjawab kriteria tinggi dan 20 responden $(18,70 \%)$ menjawab sangat tinggi.

Kebanyakan konsumen telah mengenal baik produk yang ditawarkan baik dari relasi maupun pengalaman menggunakan jasa dari pekerja sebelumnya. Sebanyak 19 responden $(17,75 \%)$ menjawab kriteria sangat tinggi, 82 responden $(76,64 \%)$ menjawab tinggi dan sisanya 6 responden $(5,60 \%)$ menjawab dengan kriteria cukup tinggi. Dengan demikian nilai rata-rata responden adalah 4,12 dengan kriteria tinggi.

Jawaban responden atas pertanyaan pembelian produk yang beragam menunjukkan 83 responden $(77,57 \%)$ menjawab tinggi dan 24 responden $(22,43 \%)$ menjawab cukup tinggi. Hal ini dikarenakan konsumen menyadari keunggulan tiap produk yang dihasilkan perusahaan sehingga mereka antusias melakukan pembelian atas produk yang beragam. Dengan demikian nilai rata-rata responden adalah 3,77 dengan kriteria tinggi.

Konsumen aktif memberikan respon terhadap produk yang tersedia dengan adanya umpan balik yang dilakukan konsumen terhadap informasi produk yang didapatnya, sehingga sebanyak 18 responden $(16,83 \%)$ menjawab sangat tinggi, 55 responden $(51,40 \%)$ menjawab tinggi dan 34 responden $(31,77 \%)$ menjawab cukup tinggi. Dengan demikian nilai rata-rata responden adalah 3,85 dengan kriteria tinggi.

Mayoritas responden menjawab dengan kriteria tinggi atas pertanyaan kesetiaan pelanggan dalam mereferensikan produk kepada orang lain. Hal ini dapat dilihat dari 25 responden $(23,36 \%)$ menjawab sangat tinggi dan 82 responden $(76,64 \%)$ menjawab tinggi. Dengan demikian nilai rata-rata responden adalah 4,23 dengan kriteria sangat tinggi.

Hampir setiap konsumen telah merasakan keuntungan dari produk dan puasnya pelayanan yang diberikan sehingga ada kesediaan pelanggan untuk menginformasikan keunggulan produk yang disediakan. Hal ini ditunjukkan dengan hasil nilai rata-rata berkriteria sangat tinggi, yaitu 4,23 , dengan rincian 26 responden $(24,30 \%)$ menjawab sangat tinggi dan 81 responden $(75,70 \%)$ menjawab tinggi.

Nilai rata-rata responden sebesar 4,19 dengan kriteria tinggi menunjukkan bahwa terdapat loyalitas dari para pelanggan, dimana 7 responden $(6,54 \%)$ menjawab cukup tinggi karena masih ada konsumen yang belum mencoba sebagian produk yang disediakan perusahaan. Selanjutnya 28 responden $(26,16 \%)$ menjawab sangat tinggi dan 72 responden $(67,30 \%)$ menjawab tinggi. 
Pertanyaan konsistensi produk perusahaan di tengah banyaknya tawaran dari perusahaan lain terhadap produk yang sama menghasilkan jawaban tinggi dari 61 responden $(57,00 \%)$ dan 46 responden $(43,00 \%)$ menjawab cukup tinggi. Hal ini dikarenakan disamping melakukan inovasi produk, perusahaan tetap menjaga konsistensi produk. Dengan demikian nilai rata-rata responden adalah 3,57 dengan kriteria tinggi.

\section{c. Analisa Deskriptif Kuantitatif}

\section{Regresi Linier Sederhana}

Penelitian ini memiliki tujuan untuk menganalisa pengaruh promosi terhadap loyalitas konsumen. Analisis data dalam penelitian ini menggunakan analisis regresi sederhana. Analisis regresi linier sederhana digunakan untuk mengetahui pengaruh variabel bebas $(\mathrm{X})$ dan variabel terikat $(\mathrm{Y})$, dimana $\mathrm{X}$ adalah promosi, dan $\mathrm{Y}$ adalah loyalitas konsumen. Analisis dilakukan dengan melakukan tabulasi jawaban responden pada kuesioner yang telah dijalankan. Untuk melihat pengaruh variabel dengan persamaan regresi tersebut, maka dilakukan perhitungan secara manual untuk memperoleh nilai a dan b, sebagai berikut:

Untuk nilai $b$ :

$$
\begin{aligned}
& \mathrm{b}=\frac{n(\Sigma X Y)-(\Sigma X)(\Sigma Y)}{n\left(\Sigma X^{2}\right)-(\Sigma X)^{2}} \\
& \mathrm{~b}=\frac{107(109176)-(3404)(3427)}{107(108444)-(3404)^{2}} \\
& \mathrm{~b}=\frac{16324}{16292} \\
& \mathbf{b}=\mathbf{1 , 0 0 1 9}
\end{aligned}
$$

Sedangkan untuk nilai a:

$$
\begin{aligned}
& \mathrm{a}=\frac{\Sigma Y-b \Sigma X}{n} \\
& \mathrm{a}=\frac{(3427)-(1,009(3404)}{107} \\
& \mathbf{a}=\mathbf{0 , 1 5}
\end{aligned}
$$

Berdasarkan hasil pengolahan data, didapat persamaan regresi linier sederhana yaitu $\hat{Y}=0,15+$ 1,00X diatas bertanda positif, artinya terdapat pengaruh yang positif antara variabel bebas (Promosi) terhadap variabel terikat (Loyalitas Konsumen) pada PT. Alam Terang Mandiri cabang Pematangsiantar. Semakin efektif kegiatan promosi akan sejalan dengan semakin tingginya loyalitas konsumen.

\section{Korelasi dan Determinasi}

Analisis distribusi frekuensi jawaban responden menurut skor dari variabel X (Promosi) dan Y (Loyalitas) dimaksud sebagaimana yang telah dilakukan, hanya bermanfaat untuk memberikan informasi pendahuluan mengenai pola distribusi jawaban responden menurut skor. Selanjutnya, dilakukan perhitungan korelasi berupa derajat atau kedalaman hubungan fungsional yang menjelaskan hubungan antar perubah, dinyatakan dengan yang dinamakan koefisien korelasi yang disimbolkan dengan r. Nilai r dapat dihitung sebagai berikut:

$$
\begin{aligned}
& r=\frac{n \sum X Y-\sum X \sum Y}{\sqrt{n \sum X^{2}-\left(\sum X\right)^{2}} \sqrt{n \sum Y^{2}-\left(\sum Y\right)^{2}}} \\
& r=\frac{107(109176)-(3404)(3427)}{\sqrt{107(108444)-(3404)^{2}} \sqrt{107(110159)-(3427)^{2}}} \\
& r=\frac{16324}{26370.58452} \\
& \mathbf{r}=\mathbf{0 , 6 2}
\end{aligned}
$$

Dari hasil perhitungan diatas, didapat nilai $r=$ 0,62 yang artinya terdapat hubungan yang kuat antara variabel $\mathrm{X}$ yaitu promosi terhadap variabel $\mathrm{Y}$ yaitu loyalitas konsumen. Selanjutnya, untuk mengukur seberapa besar variabel bebas menjelaskan variabel terikat maka digunakan koefisien determinasi (KD). Nilai KD dapat diperoleh dari:

$$
\begin{aligned}
& \mathrm{KD}=\mathrm{r}^{2} \times 100 \% \\
& \mathrm{KD}=0,62^{2} \times 100 \% \\
& \mathbf{K D}=\mathbf{3 8 , 3 0 \%}
\end{aligned}
$$

Dari hasil perhitungan di atas, dapat diketahui tinggi rendahnya loyalitas konsumen PT. Alam Terang Mandiri cabang Pematangsiantar 38,30\% dapat dijelaskan oleh promosi dan sisanya $61,70 \%$ dijelaskan oleh faktor lain yang tidak dibahas dalam penelitian, seperti kualitas produk, pelayanan jasa dan kepuasan konsumen.

\section{Uji Hipotesis (uji t)}

Untuk menguji hasil perhitungan regresi dapat dilakukan pembuktian hipotesa untuk mengetahui apakah variabel bebas mempunyai pengaruh atau tidak terhadap variabel terikat secara Parsial. Adapun hipotesa yang akan diuji secara parsial adalah:

1) Ho $=0$, bahwa tidak terdapat pengaruh yang positif antara promosi terhadap loyalitas konsumen pada PT. Alam Terang Mandiri cabang Pematangsiantar.

2) $\mathrm{Ha} \neq 0$, bahwa terdapat pengaruh yang positif antara promosi terhadap loyalitas konsumen pada PT. Alam Terang Mandiri cabang Pematangsiantar

Dengan kriteria pengujian yaitu:

a) Jika $t_{\text {hit }}<t_{\text {tab }}$ atau probabilitas signifikansi $<\alpha$ (5\%), maka Ho diterima dan Ha ditolak.

b) Jika $t_{\text {hit }}>t_{\text {tab }}$ atau probabilitas signifikansi $>\alpha$ (5\%), maka Ho ditolak dan Ha diterima.

Persentase $\alpha$ ditentukan sebesar 5\%, dimana jumlah $\mathrm{n}=107$ dan derajat kebebasan $(\mathrm{dk})=\mathrm{n}-2$

$$
\begin{aligned}
& =107-2 \\
& =105
\end{aligned}
$$

Kemudian dapat dihitung nilai $\mathrm{t}_{\text {hit }}$ sebagai berikut:

$$
\begin{aligned}
& \mathrm{t}_{\text {hit }}=\frac{r \sqrt{n-2}}{\sqrt{1-r 2}} \\
& \mathrm{t}_{\text {hit }}=\frac{0,619 \sqrt{107-2}}{\sqrt{1-(0,619)^{2}}} \\
& \mathrm{t}_{\text {hit }}=\frac{0,619 \sqrt{105}}{\sqrt{1-0,383}}
\end{aligned}
$$




$$
\begin{aligned}
t_{\text {hit }} & =\frac{0,619(10.247)}{\sqrt{0,61681}} \\
t_{\text {hit }} & =\frac{6,3431}{0,78537} \\
t_{\text {hit }} & =\mathbf{8 , 0 7}
\end{aligned}
$$

Sedangkan $\mathrm{t}_{\mathrm{tab}}$ derajat kebebasan 105 dapat dihitung dengan interpolasi sebagai berikut:

$$
\begin{gathered}
\mathrm{t}_{(5 \% ; 100)}=1,9864 \\
\mathrm{t}_{(5 \% ; 110)}=1,9818
\end{gathered}
$$

$\frac{3}{10}$

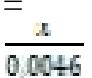

$$
\begin{aligned}
5 \times 0,0046 & =10 \mathrm{x} \\
\mathrm{X} & =0,00230
\end{aligned}
$$

Maka $\mathrm{t}_{(5 \% ; 105)}=1,9864-0,00230=1,98$

Dari perhitungan diatas tersebut, diperoleh hasil $\mathrm{t}_{\text {hit }} 8,07>\mathrm{t}_{\text {tab }}$ 1,98 maka Ho ditolak dan $\mathrm{Ha}$ diterima, artinya variabel promosi $(\mathrm{X})$ berpengaruh positif terhadap variabel loyalitas konsumen (Y). Hal ini berarti bahwa kegiatan promosi pada PT. Alam Terang Mandiri cabang Pematangsiantar berpengaruh positif terhadap loyalitas konsumen, sehingga hipotesis atau $\left(\mathrm{H}_{\mathrm{a}}\right)$ yang diajukan penulis adalah dapat diterima.

\section{a. Promosi}

2. Evaluasi

Berdasarkan hasil analisis diatas, maka penulis memberikan evaluasi terhadap PT. Alam Terang Mandiri. Pemasaran dilakukan oleh perusahaan dengan menggunakan strategi penjualan perseorangan dan promosi penjualan. Promosi telah dilakukan dengan baik, dimana segmentasi pasar yang diterapkan oleh perusahaan adalah seluruh lapisan masyarakat tanpa memandang golongan, umur dan jenis kelamin. Umumnya perusahaan menawarkan produk kepada konsumen yang ada disekitar lokasi penjualan.

Indikator promosi yang digunakan untuk mengukur tingkat loyalitas konsumen pada PT. Alam Terang Mandiri cabang Pematangsiantar, antara lain promosi penjualan (sales promotion) masih terdapat masalah dalam program yang dilakukan perusahaan guna mendorong konsumen untuk membeli produk yang telah disediakan. Oleh karena itu, perusahaan harus lebih meningkatkan program yang berhubungan dengan promosi penjualan guna mendorong pembelian produk. Selanjutnya, dalam mengubah opini masyarakat terhadap produk yang dimiliki perusahaan, perusahaan dituntut untuk membangun citra baik di masyarakat tentang produknya. Untuk itu,

\section{Saran}

a.

Dala

m kegiatan promosi diharapkan perusahaan harus lebih meningkatkan program yang berhubungan dengan promosi penjualan guna mendorong perusahaan juga harus meningkatkan perhatiannya terhadap opini yang harus dibangun dimasyarakat.

\section{b. Loyalitas Konsumen}

Berdasarkan pembahasan sebelumnya, dapat dilihat bahwa mayoritas pelanggan telah mengenal produk dan menunjukkan kesetiaan terhadap PT. Alam Terang Mandiri cabang Pematangsiantar dan produk yang ditawarkan. Akan tetapi, masih terdapat pelanggan yang menyatakan kurang mengenal PT. Alam Terang Mandiri cabang Pematangsiantar dikarenakan kesulitan menemukan lokasi yang tidak berada ditengah kota.

Pada pertanyaan membeli antar lini produk dan jasa dalam loyalitas masih terdapat masalah dalam respon konsumen terhadap produk yang disediakan. Untuk itu, perusahaan harus lebih bijaksana dalam menyikapi konsumen yang telah setia dalam menggunakan produk yang ada diperusahaan. Selanjutnya pada pertanyaan menunjukkan kekebalan terhadap pesaing, masih terdapat masalah pada konsistensi produk yang dipasarkan di tengah banyaknya tawaran dari perusahaan lain terhadap produk yang sama. Perusahaan harus meningkatkan komitmen dalam menjaga konsistensi produknya.

\section{KESIMPULAN DAN SARAN}

\section{Kesimpulan}

a. Dari hasil persentase kuesioner, menunjukkan bahwa indikator dari promosi yaitu memiliki nilai rata-rata 4,01 dengan kriteria baik. Sedangkan indikator loyalitas konsumen yaitu memiliki nilai rata-rata 4,05 dengan kriteria tinggi.

b. Berdasarkan Analisa Regresi Sederhana, diperoleh hasil $\hat{Y}=0,15+1,0019 X$, yang berarti nilai 1,0019 yang bernilai positif menunjukkan pengaruh yang positif antar promosi terhadap loyalitas pelanggan dan dapat diartikan semakin baik penerapan kegiatan promosi maka akan semakin tinggi pula loyalitas konsumen yang dapat dicapai.

c. Hasil koefisien korealsi sebesar 0,62. Ini berarti menunjukkan bahwa terdapat hubungan yang kuat antara kegiatan promosi dan loyalitas konsumen. Koefisien determinasi, ditunjukkan bahwa tinggi rendahnya loyalitas konsumen dapat dijelaskan oleh kegiatan promosi sebesar $38,30 \%$.

d. Hasil uji hipotesis menunjukkan bahwa koefisien korelasi $\mathrm{T}_{\text {hit }} 8,07>\mathrm{T}_{\text {tab }}$ 1,98. Artinya bahwa kegiatan promosi berpengaruh signifikan terhadap loyalitas konsumen. Dengan demikian, hipotesis atau $\left(\mathrm{H}_{\mathrm{a}}\right)$ yang diajukan oleh penulis dapat diterima.

pembelian produk yaitu dengan cara membagikan sampel produk berupa pakan dan obat-obatan.

b.

sahaan harus meningkatkan perhatiannya 
terhadap opini yang akan dibangun di masyarakat dengan cara membangun citra baik tentang produk mereka.

c.

k lokasi perusahaan, diharapkan perusahaan lebi mempertimbangkan tempat yang lebih strategis agar mudah dijangkau konsumen.

d.

k menjaga loyalitas konsums diharapkan perusahaan lebih bijaksana dalam menyikapi konsumen dengan cara lebih mengutamakan mereka atas produk yang ada.

m menjaga konsistensi produknya diharapkan perusahaan terus meningkatkan komitmennya dengan cara menjaga bobot produk berupa ayam boiler tersebut.

\section{E. DAFTAR PUSTAKA}

Boyd, et. al. 2000. Manajemen Pemasaran: Suatu Pendekatan Strategis dengan Orientasi Global. Erlangga, Jakarta.

Griffin, Jill. 2003. Customer Loyalty Terj Dwi Kartini Yahya. Erlangga, Jakarta.
Kotler, Philip \& Amstrong, Gary. 2004. Manajemen Pemasaran. Edisi 12, Indeks, Jakarta.

Kotler, Philip \& Amstrong, Gary. 2008. Pemasaran Dasar. jilid 16. Edisi 9. Indeks. Jakarta.

Kotler, Philip, \& Keller, Kevin Lane. 2002. Manajemen Pemasaran. PT.Prenhallindo, Jakarta. 2009. Manajemen Pemasaran. Jilid 1,Edisi 13, Erlangga, Jakarta.

Kurtz, Myer. 2008. Pengantar Bisnis. Erlangga, Jakarta.

Lupioyandi, Rambat \& A. Hamdani. 2006. Manajemen Pemasaran jasa. Edisi 2, Salemba Empat, Jakarta.

Peter, J dan Olson, J. 2002. Consumer Behavior, Perilaku Konsumen dan Strategi Pemasaran, Jilid II, Edisi Keempat, Penerbit Erlangga, Jakarta.

Sukotjo, Ibnu. 2001. Pengantar Ekonomi Perusahaan Modern. Liberty,Jakarta.

Tjiptono, Fandi. 2005. Brand Management and Strategy. Andi, Yogyakarta. 2011. Total Quality Management. Edisi V, Penerbit Andy, Yogyakarta. 